\title{
Perluasan Hutan Mangrove dalam Mitigasi Risiko Bencana Pemanasan Global: Kegiatan PkM di Kawasan Pesisir Muara Angke Jakarta
}

\author{
Rukaesih Achmad Maolani*1, Achmad Sudiyar Dalimunthe ${ }^{2}$, Dwi Haryanto ${ }^{3}$ \\ Rivo Bifa4 ${ }^{4}$ Putri Azzahra5, Cornelia Juwita6 ${ }^{6}$, Putu Egawastu Suryamika ${ }^{7}$ \\ 1,2Dosen Program Studi Manajemen, Sekolah Tinggi Manajemen Asuransi Trisakti \\ ${ }^{3}$ Dosen Program Studi Aktuaria, Sekolah Tinggi Manajemen Asuransi Trisakti \\ 4,5,6 Mahasiswa Program Studi Manajemen, Sekolah Tinggi Manajemen Asuransi Trisakti \\ ${ }^{7}$ Mahasiswa Program Studi Aktuaria, Sekolah Tinggi Manajemen Asuransi Trisakti \\ *e-mail: rukaesihmaolani44@gmail.com ${ }^{1}$, dd.dalimunthe@gmail.com ${ }^{2}$, haryantodwi2011@gmail.com ${ }^{3}$ \\ rivobifa@gmail.com ${ }^{4}$,pazzahra79@gmail.com ${ }^{5}$, cornelia08sianturi@gmail.com ${ }^{6}$, egawastu@gmail.com ${ }^{7}$
}

\begin{abstract}
One of the disasters caused by humans is global warming. Global warming is a big problem that is being faced by all human beings and living things on earth. One of the activities that can be carried out in mitigating the risk of global warming is through Mangrove Ecosystem Rehabilitation. The existence of the Mangrove ecosystem in the coastal area of DKI Jakarta Province is currently experiencing a decline in line with the development that changes the function of the area from a protected function to a cultivation function. One area that has experienced this is the coastal area in Muara Angke which has had a negative impact on the environment, namely the function of protecting and securing the coast will naturally be lost. In this 2021 Community Service program, STMA Trisakti has participated in helping to solve the problem of the rate of degradation of the Mangrove Forest by planting 1000 mangrove seedlings in the Muara Angke Eco-tourism area. The planting was carried out on World Environment Day on 5 June 2021.
\end{abstract}

Keywords: Risk Mitigation, Global Warming, Expansion of the Mangrove Forest

\begin{abstract}
Abstrak
Salah satu bencana yang disebabkan oleh manusia adalah terjadinya pemanasan global. Pemanasan global merupakan masalah besar yang sedang dihadapi oleh seluruh umat manusia dan makhluk hidup di bumi. Salah satu kegiatan yang dapat dilakukan dalam mitigasi risiko terjadinya pemanasan global adalah melalui Rehabilitasi Ekosistem Mangrove. Keberadaan ekosistem Mangrove di kawasan pesisir Provinsi DKI Jakarta saat ini mengalami penurunan seiring dengan adanya pembangunan yang mengubah fungsi kawasan dari fungsi lindung ke fungsi budidaya. Salah satu daerah yang mengalami hal tersebut adalah wilayah pesisir di Muara Angke yang telah memberikan dampak negatif bagi lingkungan, yaitu fungsi perlindungan dan pengamanan pantai secara alami akan hilang. Dalam program Pengabdian kepada Masyarakat tahun 2021 ini, STMA Trisakti telah turut serta membantu solusi permasalahan terjadinya laju degradasi Hutan Mangrove dengan melakukan penanaman bibit mangrove sebanyak 1000 pohon di kawasan Eko-Wisata Muara Angke. Penanaman telah dilaksanakan pada Hari Lingkungan Hidup Sedunia tanggal 5 Juni 2021.
\end{abstract}

Kata kunci: Mitigasi Risiko, Pemanasan Global, Perluasan Hutan Mangrove

\section{PENDAHULUAN}

Bencana alam akhir-akhir ini merupakan salah satu yang menjadi topik perbincangan masyarakat di samping permasalahan terjadinya pandemi Covid-19. Saat ini di beberapa wilayah Indonesia bencana yang terjadi mulai dari tanah longsor, banjir, gempa bumi, gunung meletus, dan lainnya. Bencana adalah peristiwa atau rangkaian peristiwa yang mengancam dan mengganggu kehidupan dan penghidupan masyarakat yang disebabkan baik oleh faktor alam dan/atau faktor non alam maupun faktor manusia. Bencana yang disebabkan faktor alam misalnya gempa bumi, gunung meletus, tsunami dan lain sebagainya, sedangkan bencana yang disebabkan manusia salah satunya adalah terjadinya pemanasan global yang memberikan berbagai dampak terhadap kehidupan manusia.

Pemanasan global didefinisikan sebagai kenaikan suhu rata-rata permukaan bumi yang disebabkan oleh meningkatnya konsentrasi dari gas rumah kaca seperti: gas $\mathrm{CO}_{2}$, gas metana $\left(\mathrm{CH}_{4}\right)$, uap air, dan $\mathrm{N}_{2} \mathrm{O}$ (Al-Ghussain, 2019). Peningkatan suhu bumi ini dipengaruhi oleh 
berbagai macam faktor yang berasal dari aktivitas manusia, mulai dari aktivitas pembakaran bahan bakar fosil untuk kegiatan industri maupun transportasi, tindakan penggundulan hutan, serta aktivitas pertanian dan peternakan yang dilakukan oleh sebagian besar masyarakat. Beberapa aktivitas manusia ini ternyata menghasilkan antara lain emisi karbon berupa gas $\mathrm{CO}_{2}$ dan $\mathrm{CH}_{4}$ yang berdampak pada efek rumah kaca. Metana $\left(\mathrm{CH}_{4}\right)$ merupakan salah satu gas rumah kaca yang menyebabkan efek rumah kaca dengan memiliki efek 20-30 kali lebih besar dibandingkan dengan gas $\mathrm{CO}_{2}$ (Kusumawardhani \& Gernowo, 2015).

Dampak pemanasan global yang pertama adalah naiknya suhu bumi. Berdasarkan hasil pengamatan, selama tahun 2015 dikatakan sebagai tahun terpanas dalam sepanjang sejarah. Naiknya gelombang panas bumi ini pun diperkirakan akan terus terjadi di tahun-tahun berikutnya. Pada satu abad terakhir ini, bahkan suhu bumi tercatat makin menghangat hingga 0,6 derajat Celsius. Para ilmuwan memprediksi, di akhir abad ini kenaikan suhu itu akan meningkat hingga sekitar 6 derajat Celsius (Drake, 2001). Pemanasan global selama abad terakhir ini telah mengakibatkan perubahan iklim yang sebagian besar terindikasi sebagai bencana lingkungan hidup, seperti banjir, kekeringan dan bergesernya musim hujan (Rasmikayati \& Djuwendah, 2015). Hal ini yang dapat menyebabkan terjadinya perubahan pada pendapatan para petani.

Selain suhu bumi yang semakin panas, kondisi pemanasan global juga berdampak pada naiknya permukaan air laut yang disebabkan mencairnya es di daerah kutub. Kondisi ini tentu akan mengancam pulau-pulau yang ada di dataran rendah serta kota-kota yang berdekatan dengan pesisir pantai. Dengan begitu, jika kondisi pemanasan global tidak segera ditangani bisa merusak dan menghancurkan kehidupan manusia dan berbagai makhluk bumi lainnya. Selain itu seperti dikemukakan oleh Raksanagara et al., (2016) dari hasil penelitiannya menyimpulkan bahwa adanya perubahan suhu, curah hujan dan kelembaban akan menyebabkan penyakit demam berdarah. Dengan banyaknya dampak yang akan dialami oleh masyarakat akibat terjadinya perubahan iklim, (Perdinan, 2020) mengemukakan perlunya ketersediaan dan akses informasi iklim yang sangat diperlukan dalam penilaian dampak sebagai langkah awal dalam penyusunan langkah-langkah adaptasi. Selanjutnya Haryanto \& Prahara, (2019) dari hasil penelitiannya menyimpulkan bahwa perubahan iklim merupakan akibat perilaku individu, oleh karena itu upaya menyelesaikan permasalahannya harus melalui perubahan gaya hidup keseharian yang pro terhadap lingkungan. Mustangin, (2017) mengemukakan bahwa dalam menghadapi perubahan iklim dan aksi menghadapi dampaknya diperlukan pola keterlibatan perempuan yang dimulai dari awal peningkatan kesadaran untuk ikut serta terlibat

Akibat besarnya dampak dari pemanasan global ini maka diperlukan upaya-upaya menanggulanginya berupa mitigasi risiko bencana alam. Mitigasi bencana merupakan serangkaian upaya untuk mengurangi risiko bencana agar dampak dari kejadian bencana bisa di minimalisir. Mitigasi bencana menjadi bagian dari tahap awal penanggulangan bencana atau pra bencana. Salah satu kegiatan yang dapat dilakukan dalam melakukan mitigasi risiko terjadinya pemanasan global adalah melalui "Rehabilitasi Ekosistem Mangrove".

Ekosistem mangrove sering disebut sebagai hutan bakau, merupakan tipe hutan daerah tropis yang khas tumbuh di sepanjang pantai atau muara sungai yang masih dipengaruhi oleh pasang surut air laut. Ekosistem mangrove merupakan ekosistem yang unik dan rawan, tetapi mempunyai peranan fungsi multi guna baik jasa biologis, ekologis, maupun ekonomis. Seperti yang dikemukakan oleh Heni Irawati et al., (2020) tanaman mangrove dapat dimanfaatkan sebagai pewarna alam disamping memberikan nuansa warna alami dan motif yang indah, juga dapat mengurangi pencemaran lingkungan. Peranan fungsi fisik mangrove mampu mengendalikan abrasi dan intrusi air laut ke wilayah daratan, serta mampu menahan sampah yang berasal dari daratan, yang dikendalikan melalui sistem perakarannya. Jasa biologis mangrove sebagai sempadan pantai berperan sebagai penahan gelombang dan memperlambat arus pasang surut. Selain itu komunitas mangrove juga merupakan sumber unsur hara bagi kehidupan hayati (biota perairan laut), serta sumber pakan bagi kehidupan biota darat seperti burung, mamalia, dan jenis reptil. Selain itu pemanfaatan tanaman mangrove dapat memberikan peningkatan kualitas hidup masyarakat, antara lain meningkatnya estetika spiritual, dan nilai- 
nilai lain yang berkaitan dengan kesejahteraan sampai pada meningkatkan pendapatan ekonomi rumah tangga (Sari, 2016).

Keberadaan ekosistem mangrove di kawasan pesisir Provinsi DKI Jakarta saat ini mengalami penurunan seiring dengan makin berkembangnya pembangunan yang mengubah fungsi kawasan dari fungsi lindung ke fungsi budidaya. Salah satu daerah yang mengalami hal tersebut adalah wilayah pesisir di Muara Angke. Berkurangnya Mangrove di pesisir Muara Angke dikarenakan oleh konversi lahan pada beberapa daerah dari Hutan Mangrove menjadi daerah industri dan perumahan mewah. Hal tersebut memberikan dampak negatif bagi lingkungan, yaitu fungsi perlindungan dan pengamanan pantai secara alami akan hilang. Bagi perekonomian masyarakat, penurunan luasan Hutan Mangrove menyebabkan penurunan produksi di sektor perikanan yang berbanding lurus dengan hilangnya areal hutan mangrove, hal ini berakibat pada menurunnya pendapatan masyarakat.

United Nation Environment Programme (UNEP) menetapkan tema Hari Lingkungan Hidup Sedunia tangal 5 Juni tahun 2021 adalah Restorasi Ekosistem. Kegiatan yang dilakukan dapat mengambil banyak bentuk seperti menanam pohon, menghijaukan kota, membangun kembali kebun, mengubah pola makan atau membersihkan sungai dan pantai. Restorasi ini dilakukan untuk membentuk generasi kedepan yang dapat berdamai dengan alam. Otoritas Jasa Keuangan menerbitkan Peraturan OJK 51/POJK.03/2017 tentang Keuangan Berkelanjutan Bagi Lembaga Jasa Keuanan Non Bank, yang salah satu kategori kegiatan adalah efisiensi dan konservasi energy. Perusahaan jasa keuangan non bank diminta membuat rencana aksi dan menyampaikan laporan kegiatan dalam rangka program keuangan berkelanjutan tersebut $(0 J \mathrm{~K}, 2017)$.

Dalam mengisi Hari Lingkungan Hidup Sedunia tanggal 5 Juni 2021, sudah sewajarnya ada kegiatan Tri Dharma Perguruan Tinggi dalam bentuk Pengabdian Kepada Masyarakat (PKM). Kegiatan PKM yang dilakukan oleh dosen bersama mahasiswanya dalam hal ini sudah sesuai dengan kebijakan menurunkan emisi Gas Rumah Kaca (GRK) secara sukarela pada tahun 2020 yang telah menjadi komitmen Indonesia untuk berperan dalam penurunan emisi GRK secara global (KLH, 2012).

\section{METODE}

Metode pelaksanaan yang yang digunakan pada kegiatan PKM ini adalah:

1. Survei pendahuluan ke lokasi penanaman mangrove

Untuk persiapan melakukan PKM penanaman bibit pohon Mangrove di lokasi yang sudah ditetapkan, langkah pertama adalah survei pendahuluan ke lokasi penanaman sambil meminta izin kepada Pengelola Hutan Mangrove di Muara Angke Jakarta Utara akan adanya kegiatan PKM yang dilakukan oleh tim dari Sekolah Tinggi Manajemen Asuransi Trisakti (STMA Trisakti). Survei pendahuluan ini dilaksanakan pada bulan Maret 2021.

2. Penyusunan proposal PKM

Untuk kegiatan PKM yang dilakukan dosen dan mahasiswa di Perguruan Tinggi perlu adanya suatu proposal yang diajukan kepada Pengelola Hutan Mangrove untuk meminta izin penanaman bibit pohon Manrove yang akan dilakukan oleh tim PKM STMA Trisakti bersama dengan para donatur dari Perusahaan Asuransi. Selain itu Proposal PKM dibutuhkan untuk menyertai/lampiran permohonan bantuan dana dari donatur.

3. Pengajuan proposal kerjasama kepada beberapa perusahaan asuransi

Biaya yang dibutuhkan untuk menanam bibit pohon Mangrove cukup banyak, oleh karena itu perlu meminta bantuan donasi dari beberapa perusahaan. Untuk itu disusun proposal yang kemudian dikirim ke beberapa Perusahaan Asuransi. Dengan cara ini berhasil dikumpulkan donasi dari 9 (Sembilan) Perusahaan Asuransi untuk melaksanakan penanaman 1000 (seribu) bibit pohon Mangrove di Wilayah Eko-Wisata Hutan Mangrove Muara Angke Jakarta Utara. 
4. Pembentukan panitia pelaksanaan kegiatan PKM

Untuk mempersiapkan kegiatan penanaman bibit pohon Mangrove di lokasi penanaman perlu dilakukan pembentukan panitian pelaksana kegiata PKM yang terdiri dari tim dosen, staf administrasi dan mahasiswa yang berasal dari Prodi Manajemen dan Prodi Aktuaria.

5. Pelaksanaan kegiatan penanaman bibit Mangrove

Kegiatan penanaman bibit Mangrove dilaksanakan pada hari Sabtu, 5 Juni 2021. Acara pelaksanaan penanaman bibit pohon Mangrove diawali dengan kegiatan acara pembukaan yang bersifat resmi, yang dimulai oleh laporan kegiatan pelaksanaan penanaman yang disampaikan oleh Ketua kegiatan PKM, kemudian disusul dengan sambutan-sambutan yang diawali oleh Ketua STMA Trisakti, Ketua Umum Badan Pengurus Yayasan Trisakti, Sekretaris Ketua LLDIKTI Wilayah III, Direktur Pengawasan Asuransi dan BPJS Kesehatan OJK, Ketua Komisi Komunikasi DAI, Direktur Eksekutif AAUI, Kepala Seksi Konservasi dan Sumber Daya Hutan Dinas Pertamanan dan Hutan Kota Provinsi DKI Jakarta, kemudian Wakil dari para sponsor yang ikut serta dalam membantu biaya kegiatan penanaman pohon mangrove. Setelah acara pembukaan selesai dilakukan penanaman bibit pohon mangrove oleh seluruh peserta dengan dipandu oleh Bapak Ujang (ketua kelompok petani Mangrove).

\section{Pemantauan}

Pertumbuhan pohon Mangrove yang baru ditanam perlu dilakukan pemantauan secara teratur dan berkesinambungan. Setiap bulan sekali dilakukan pemantauan terhadap pertumbuhannya oleh petani yang diberi tugas untuk merawat pertumbuhan dengan cara mengukur tinggi pohon Mangrove secara rata-rata yang kemudian dilaporkan kepada Ketua Tim PKM STMA Trisakti. Oleh karena disediakan biaya perawatan untuk selama 2 (dua) tahun kepada pengelola petani dilokasi tanam, bila ada tanaman yang mati diganti dengan tanaman yang baru sehingga jumlah pohon yang ditanam relatif konstan jumlahnya (1000 pohon).

\section{HASIL DAN PEMBAHASAN}

Kegiatan penanaman bibit Mangrove dilaksanakan pada hari Sabtu, 5 Juni 2021 bertepatan dengan Hari Lingkungan Hidup Sedunia di Wilayah Eko-Wisata Hutan Mangrove Muara Angke Jakarta Utara. Kegiatan ini diawali dengan acara pembukaan secara resmi yang dihadiri oleh Tim PKM (Dosen dan Mahasiswa), Pengelola Hutan Mangrove, Pimpinan STMA Trisakti, Ketua Umum Badan Pengurus Yayasan Trisakti, Sekretaris LLDIKTI Wilayah III, dan perwakilan dari perusahaan sponsor. Acara pembukaan diawali dengan laporan dari Ketua PKM yang dilanjutkan dengan sambutan dari Ketua STMA Trisakti, Ketua Umum Badan Pengurus Yayasan Trisakti, Sekretaris LLDIKTI Wilayah III, Direktur Pengawasan Asuransi dan BPJS Kesehatan OJK, Ketua Komisi Komunikasi DAI, Direktur Eksekutif AAUI, dan Kepala Seksi Konservasi dan Sumber Daya Hutan Dinas Pertamanan dan Hutan Kota Provinsi DKI Jakarta. Berikut ini beberapa dokumentasi pada saat acara pembukaan.

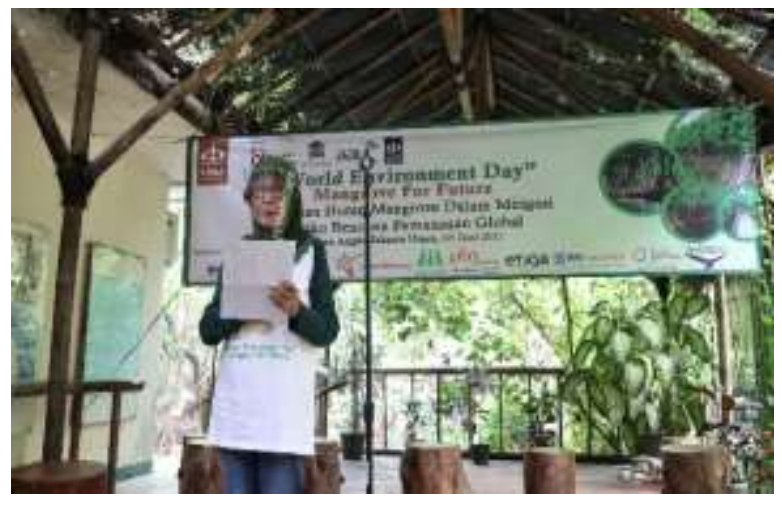

(a)

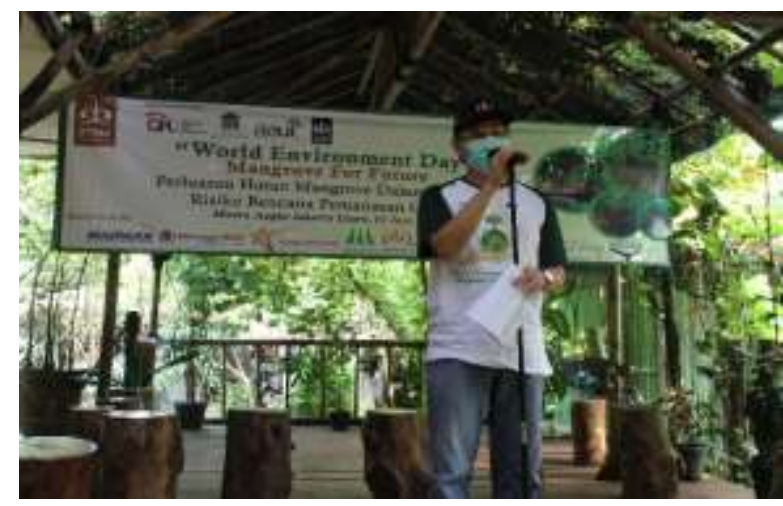

(b)

Gambar 1. (a) Sambutan Ketua PKM dan (b) Ketua STMA Trisakti 


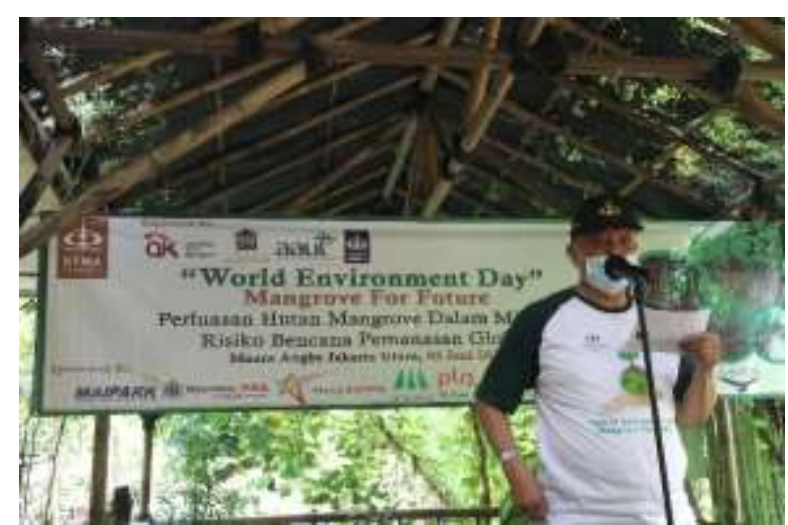

(a)

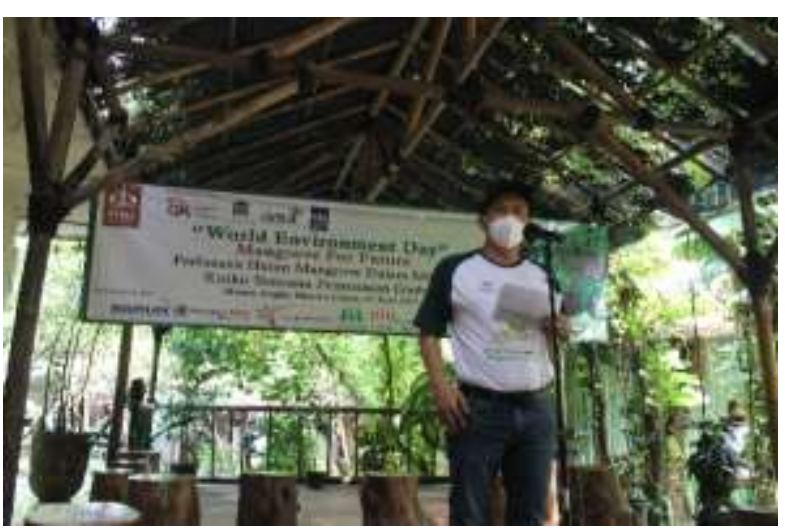

(b)

Gambar 2. (a) Sambutan Ketua Umum Badan Pengurus Yayasan Trisakti dan (b) Sekretaris LLDIKTI Wilayah III

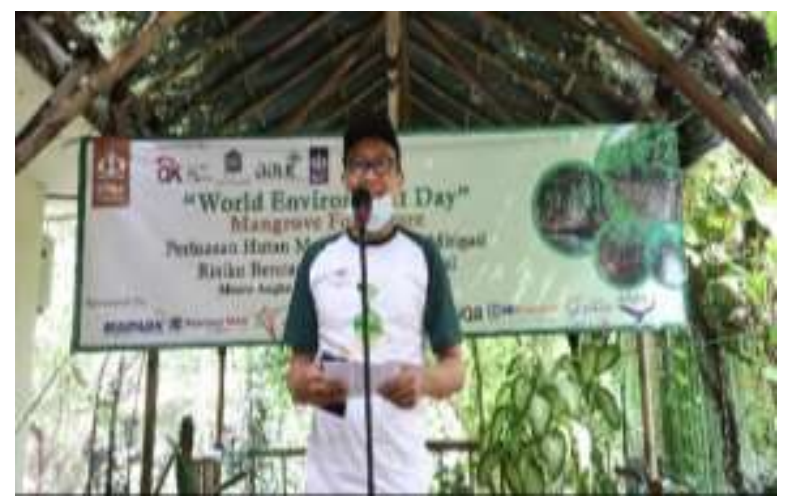

(a)

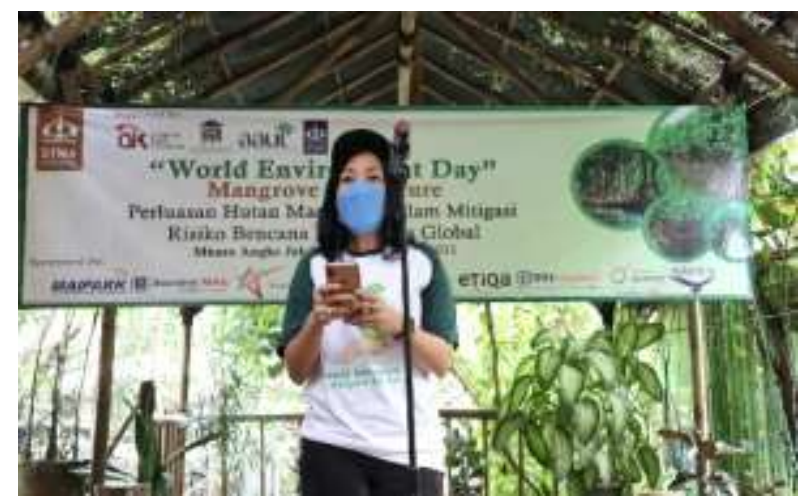

(b)

Gambar 3. (a) Sambutan Direktur Pengawasan Asuransi dan BPJS Kesehatan OJK dan (b) Ketua Komisi Komunikasi DAI

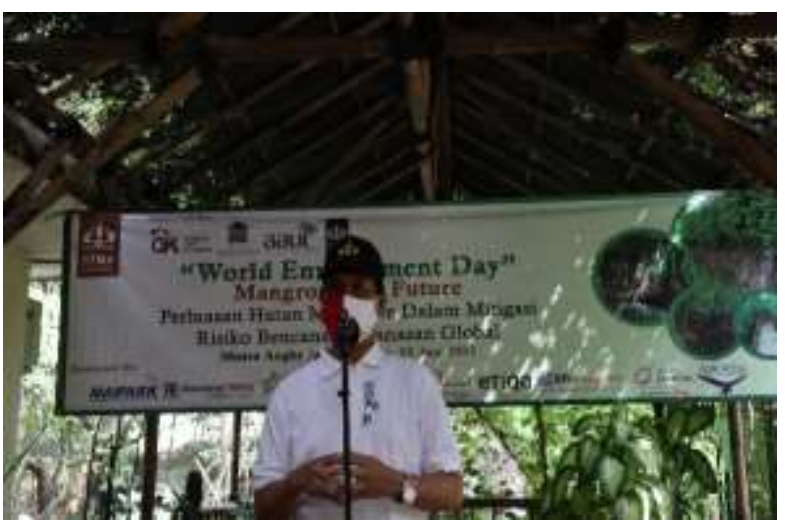

(a)

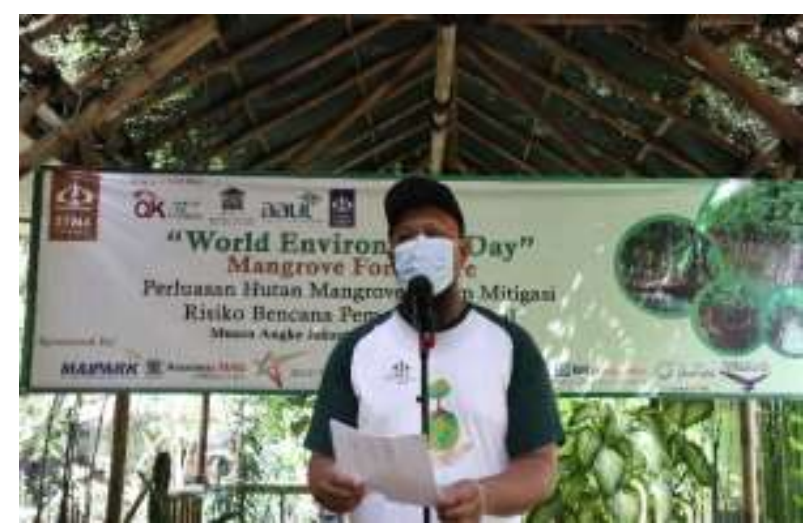

(b)

Gambar 4. (a) Sambutan Direktur Eksekutif AAUI dan (b) Kepala Seksi Konservasi dan Sumber Daya Hutan Dinas Pertamanan dan Hutan Kota Provinsi DKI Jakarta

Kemudian acara dilanjutkan dengan pemberian sertifikat penghargaan kepada para sponsor yang turut berpartisipasi pada kegiatan PKM ini. Berikut ini beberapa dokumentasi pada saat pemberian sertifikat penghargaan. 

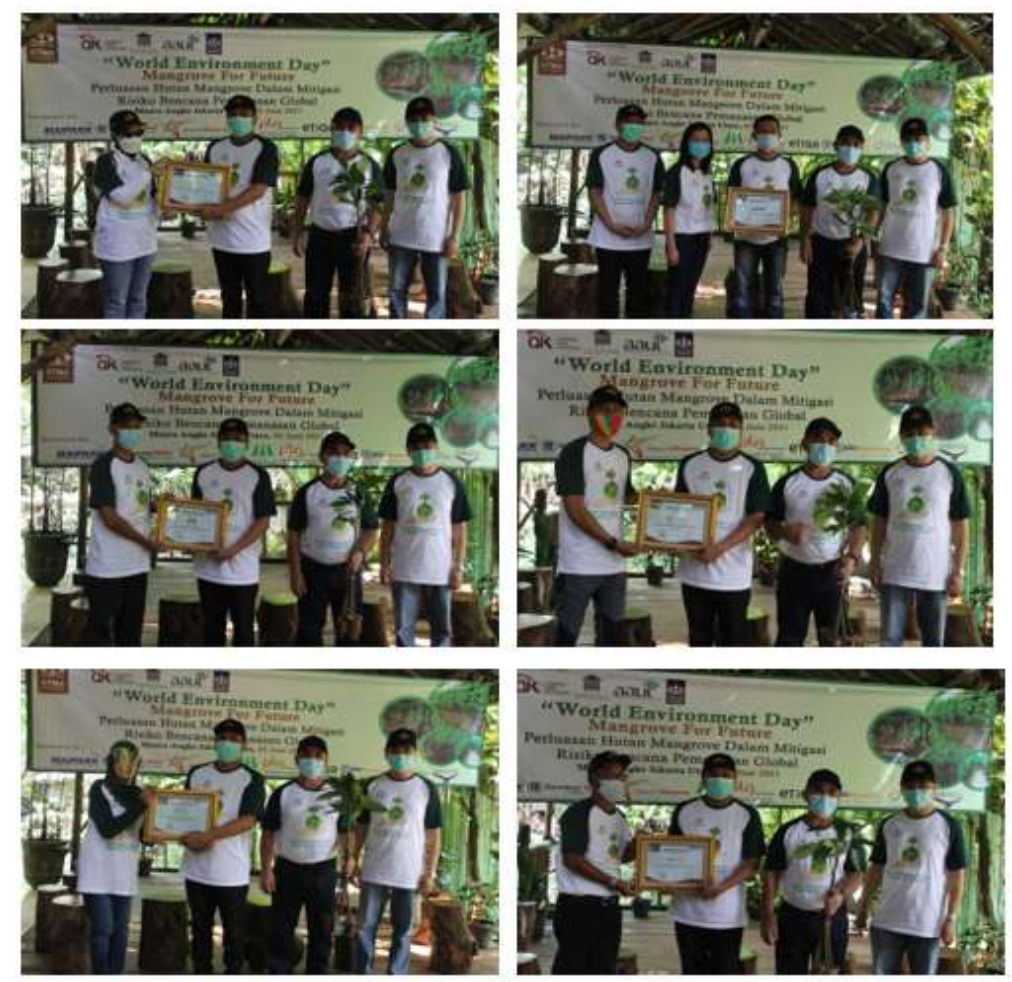

Gambar 5. Pemberian Sertifikat Penghargaan Kepada Perusahaan Sponsor

Rangkaian acara pembukaan ditutup dengan foto bersama seluruh peserta yang mengikuti kegiatan penanaman bibit mangrove. Selanjutnya seluruh peserta yang hadir pada kegiatan PKM ini menuju ke lokasi penanaman dengan berjalan kaki selama kurang lebih 15 menit dari lokasi acara pembukaan. Acara penanaman berlangsung selama kurang lebih dua jam. Pada proses penanaman seluruh peserta mengenakan sarung tangan dan tetap memakai masker sebagai bentuk menerapkan protokol kesehatan. Proses penanaman ini dipandu oleh Bapak Ujang selaku pengelola Mangrove dan dibantu oleh beberapa petani. Adapun total yang ditanam sebanyak 1000 bibit mangrove. Berikut ini beberapa dokumentasinya.
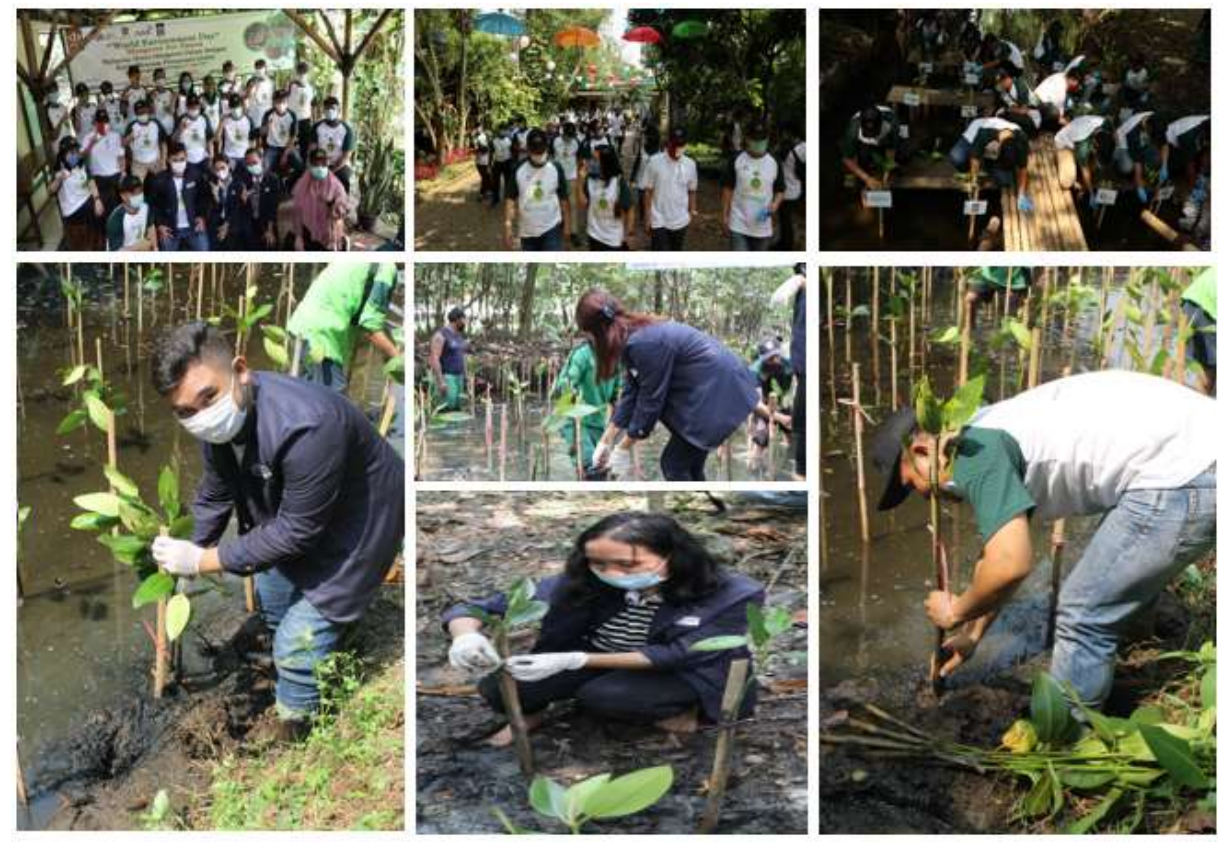

Gambar 6. Proses Penanaman 1000 Bibit Mangrove 

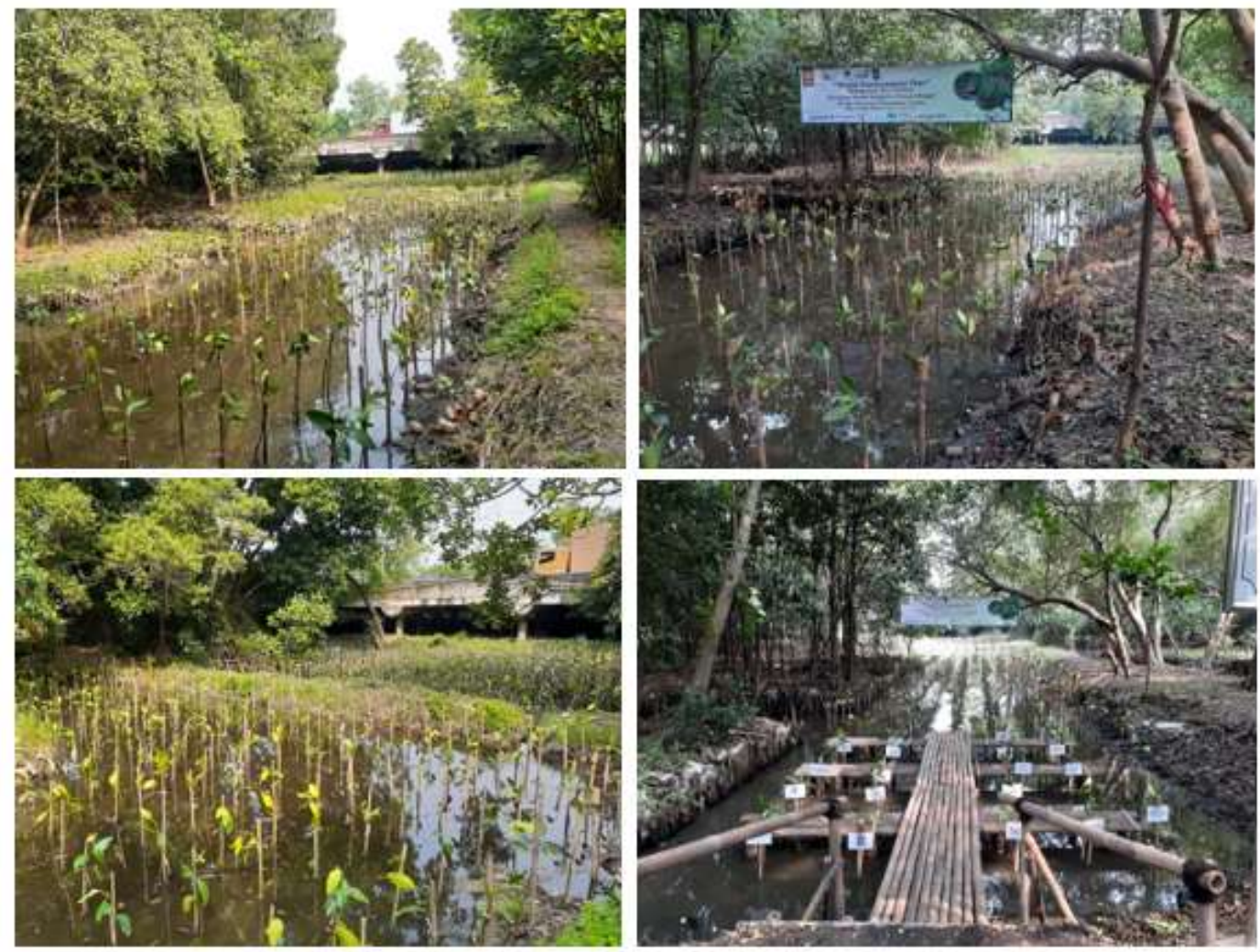

Gambar 7. Mangrove yang Sudah di Tanam

Dari bibit mangrove yang telah ditanam tersebut dilakukan pemantauan secara teratur dan berkesinambungan. Setiap bulan sekali dilakukan pemantauan terhadap pertumbuhannya oleh petani dengan cara mengukur tinggi pohon Mangrove secara rata-rata yang kemudian dilaporkan kepada Ketua Tim PKM STMA Trisakti. Tim PKM dosen juga sewaktu waktu melakukan pemantauan untuk mengamati pertumbuhan dari pohon Mangrove yang baru ditanam. Pada awal penanaman tinggi bibit mangrove sekitar $80 \mathrm{~cm}$. Kemuidan hingga akhir September 2021, rata-rata tinggi mangrove sekitar $93 \mathrm{~cm}$. Berikut ini disajikan data rata-rata kenaikan tinggi bibit Mangrove per bulannya.

Tabel 1. Rata-Rata Kenaikan Tinggi Tanaman Mangrove Per Bulan

\begin{tabular}{ccc}
\hline Bulan & $\begin{array}{c}\text { Tinggi Tanaman Saat } \\
\text { Pengukuran }(\mathrm{cm})\end{array}$ & $\begin{array}{c}\text { Rata-Rata Kenaikan Tinggi Tamanam } \\
\text { dari Pengukuran Sebelumnya }(\mathrm{cm})\end{array}$ \\
\hline Juni & 80 & 3 \\
Juli & 83 & 5 \\
Agustus & 88 & 5 \\
September & 93 & 5 \\
\hline
\end{tabular}

Kemudian, berikut ini dokumentasi kegiatan pemantauan yang dilakukan oleh Tim PKM STMA Trisakti. 

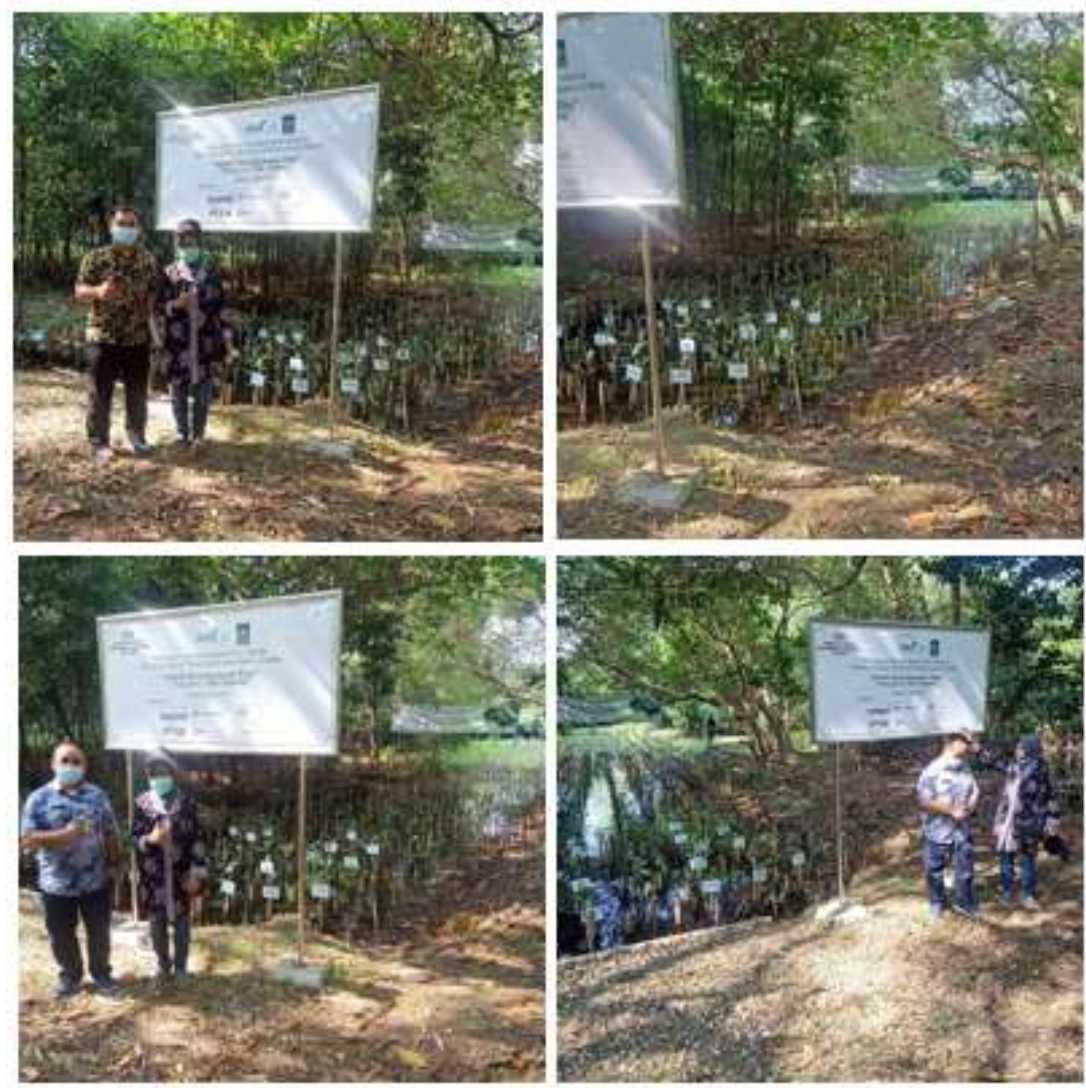

Gambar 8. Kegiatan Pemantuan yang Dilakukan oleh Tim PKM STMA Trisakti

\section{KESIMPULAN} berikut:

Dari kegiatan PKM yang telah dilaksanakan dapat disimpulkan beberapa hal sebagai

1. Berhasilnya penanaman bibit mangrove sebanyakan 1000 pohon di lokasi Eko Wisata Muara Angke Jakarta Utara.

2. Terjalinnya kerjasama yang saling menguntungkan antara Perguruang Tinggi (STMA Trisakti) dengan pihak di luar Perguruan Tinggi, seperti dengan Asosiasi Asuransi Umum Indonesia (AAUI), Dewan Asuransi Indonesia (DAI), dan Otoritas Jasa Keuangan (OJK), untuk bersama-sama menyelenggarakan kegiatan PKM.

3. Perusahaan asuransi dan reasuransi dapat megimplementasikan ketentuan dalam Peraturan OJK 51/POJK.03/2017 tentang Keuangan Berkelanjutan Bagi Lembaga Jasa Keuanan Non Bank melalui kegiatan koservasi lingkungan.

4. Terjaliannya kerjasama dengan para sponsor perusahaan asuransi dalam menggunakan dana Corporate Social Responsibility (CSR) nya untuk kegiatan PKM.

5. Pada awal penanaman, tinggi bibit mangrove sekitar $80 \mathrm{~cm}$.

6. Rata-rata tinggi pohon mangrove dari penanaman (5 Juni) sampai akhir September yaitu $93 \mathrm{~cm}$.

7. Rata-rata kenaikan tinggi bibit mangrove setiap bulannya yaitu $3-5 \mathrm{~cm}$.

8. Pohon mangrove perlu dilakukan pemantauan agar ketika ditemukan pohon yang mati maka dapat diganti dengan bibit yang baru.

\section{UCAPAN TERIMA KASIH}

Penulis mengucapkan terima kasih kepada Dinas Pertamanan dan Hutan Kota Provinsi DKI Jakarta, LLDIKTI Wilayah III, Asosiasi Asuransi Umum Indonesia (AAUI), Dewan Asuransi 
Indonesia (DAI), dan Otoritas Jasa Keuangan (OJK) yang telah mendukung dan berpartisipasi kegiatan PKM ini. Penulis juga mengucapkan terima kasih kepada PT. Reasuransi MAIPARK Indonesia, PT. Maskapai Reasuransi Indonesia, PT. Asuransi Multi Artha Guna, PT. Asuransi Bintang, PT. Asuransi Etiqa Internasional Indonesia, PT. BRI Insurance, PT. PLN Insurance, PT. Asuransi Bangun Askrida, dan PT. Asuransi Jasindo yang telah menjadi sponsor dalam kegiatan PKM ini.

\section{DAFTAR PUSTAKA}

Al-Ghussain, L. (2019). Global warming: review on driving forces and mitigation. Environmental Progress and Sustainable Energy, 38(1), 13-21. https://doi.org/10.1002/ep.13041

Drake, F. (2001). Global Warming : Fenomena Bencana yang Tak Bisa Dianggap Ringan. 2(1).

Haryanto, H. C., \& Prahara, S. A. (2019). Perubahan Iklim, Siapa Yang Bertanggung Jawab? Insight: Jurnal Ilmiah Psikologi, 21(2), 50. https://doi.org/10.26486/psikologi.v21i2.811

Heni Irawati, Novi Luthfiyana, Imra, Triyana Wijayanti, Andi Izza Naafilah, \& Sari Wulan. (2020). Aplikasi Pewarnaan Bahan Alam Mangrove Pada Kain Batik Sebagai Diversifikasi Usaha Masyarakat. Dinamisia: Jurnal Pengabdian Kepada Masyarakat, 4(2), 285-292. https://doi.org/10.31849/dinamisia.v4i2.3982

KLH. (2012). Kebijakan Penurunan Emisi Gas Rumah Kaca 26\%.

Kusumawardhani, I. D., \& Gernowo, R. (2015). Analisis Perubahan Iklim Berbagai Variabilitas Curah Hujan Dan Emisi Gas Metana ( $\mathrm{CH} 4$ ) Dengan Metode Grid Analysis And Display System ( GrADS ) di Kabupaten Semarang Pemanasan global merupakan naiknya suhu rata-rata diseluruh permukaan bumi akibat dari. Youngster Physic Journal, 4(1), 49-54.

Mustangin, M. (2017). Perubahan iklim dan aksi menghadapi dampaknya: Ditinjau dari peran serta perempuan Desa Pagerwangi. Jurnal Pendidikan Dan Pemberdayaan Masyarakat, 4(1), 80. https://doi.org/10.21831/jppm.v4i1.13051

OJK. (2017). POJK Nomor 51/POJK.03/2017. 1-15.

Perdinan, P. (2020). Perubahan Iklim Dan Demokrasi: Ketersediaan Dan Akses Informasi Iklim, Peranan Pemerintah, Dan Partisipasi Masyarakat Dalam Mendukung Implementasi Adaptasi Perubahan Iklim Di Indonesia. Jurnal Hukum Lingkungan Indonesia, 1(1), 109-132. https://doi.org/10.38011/jhli.v1i1.87

Raksanagara, A., Arisanti, N., \& Rinawan, F. (2016). Dampak Perubahan Iklim Terhadap Kejadian Demam Berdarah Di Jawa-Barat. Jurnal Sistem Kesehatan, 1(1), 43-47. https://doi.org/10.24198/jsk.v1i1.10339

Rasmikayati, E., \& Djuwendah, E. (2015). Dampak Perubahan Iklim Terhadap Perilaku Dan Pendapatan Petani (The Impact of Climate Change to Farmers' Behavior and Revenue). Jurnal Manusia Dan Lingkungan, 22(3), 372. https://doi.org/10.22146/jml.18764

Sari, R. (2016). Penggunaan Mangrove Untuk Meningkatkan Pendapatan Ekonomi Rumah Tangga. Jurnal Pengabdian Kepada Masyarakat, 22(4), 10-15. https://jurnal.unimed.ac.id/2012/index.php/jpkm/article/view/5753 